\title{
ЭЛЭГНИЙ ХОРТ ХАВДРЫН IN VITRO ДАХЬ ЭСИЙН ҮЙЛ АЖИЛЛАГААГ ЭМИЙН БАГВААХАЙГААС (TARАХАСUМ OFFICINALE WIGG F.H.) ЯЛГАСАН ЗАРИМ БОДИС ДАРАНГУЙЛЖ БУЙ БАЙДАЛ
}

\author{
Ж.Болдбаатар ${ }^{1}$, Б.Түвшинтөгс ${ }^{1}$, О.Одгэрэл ${ }^{1}$, Г.Одонтуяа ${ }^{2}$, \\ Р.Сандуйжав ${ }^{3}$, П.Эрдэнэбаатар ${ }^{1}$, Ц.Оюунсүрэн \\ ${ }^{1}$ ШУА-ийн Биологийн хүрээлэнгийн Молекул биологийн лаборатори \\ ${ }^{2}$ ШУА-ийн Хими хими-технологийн хүрээлэнгийн Байгалийн нэгдлийн химийн лаборатори \\ ${ }^{3}$ Хавдар судлалын Үндэсний Төв \\ tsosuren@yahoo.com
}

\section{Хураангуй}

Манай орны хүн амын дунд элэгний хорт хавдар буюу анхдагч өмөн нь бусад хавдартай харьцуулахад хамгийн их тохиолдох ба нас баралтын хувь хэмжээ ихтэй өвчин юм. Иймээс энэ өвчнөөс урьдчилан сэргийлэх, эрт уед нь оношлох, эмчлэх нь ихээхэн чухал болоод байна.

Бид уламжлалт анагаах ухаанд өргөн хэрэглэгддэг Эмийн багваахай (Taraxacum officinale Wigg.S.L)-ट элэгний хорт хавдарын эмчилгээнд ашиглах боломжийг судлах зорилгоор уг ургамлаас хэд хэдэн ханд, бодис гарган авч эдгээр нь хорт хавдарын in vitro дахь эсийн өсгөвөрийн үйл ажиллагаанд хэрхэн нөлөөлж буйг илруүлэх ажлыट хийв.

Судалгаанд элэгний хавдрын анхдагч эсийн өсгөвөр (PCC), элэгний хавдрын шугаман эс HерG2 болон T.officinale-н газрын дээд хэсгийн дихлорметанан (ДХМ) ханд, түүнээс ялгасан тараксастерилацетат, псевдотараксастерол, тараксастерол, b-ситостерол, пальмитиний хүчил, b-ситостерил глюкоз гэсэн 6 бодис ашиглав.

Бидний судалгааны үр дүнд ДХМ ханд нь элэгний хавдарын эсийн хуваагдалд сөргөөр нөлөөлж, эсийн үсэрхийлэх хурдыट 36\%-р, суух чадварыट 2.6 дахин, наалдах чадварыट 34.5\%-p тус тус бууруулж, Bcl-2 болон ZPYVE-1 зэрэг генүүдийн экспрессийг дарангуйлж байв.

Дээрх бодисуудаас пальмитиний хүчил нь эсийн хуваагдал, шилжин хөдлөх чадвар, эс хоорондын наалдах чадвар, эсийн суух чадвар зэрэг үйл ажиллагааг бууруулж байсан ба эсийн апоптози болон эсийн бүтцийн эвдрэл идэвхижихэд нөлөө үзуүлсэн.

Эдгээрээс үндэслэж T.officinale-н ДХМ ханд, түүнээс ялгасан пальмитиний хүчил нь элэгний хавдрын эсийн үйл ажиллагаанд сөрөг нөлөө үзүүлж байна гэж дүгнэв.

Түлхүур уг: Taraxacum officinale, HepG2, эсийн хуваагдал, адгези, апоптози, пальмитиний хүчил 


\section{ОРшил}

Дэлхий олон оронд төрөл бүрийн хорт хавдрын өвчлөл болон түүнээс шалтгаант эндэгдлийн тоо тасралтгүй өсөж байгаагийн [1] улмаас уг өвчний эмчилгээнд химийн ба туяа эмчилгээ зэргийг түлхүу хэрэглэх авч тэдгээр нь гаж нөлөө ихтэй, өртөг өндөртэй учир байгалийн гаралтай, сөрөг нөлөө багатай эм, бэлдмэл гарган авч ашиглах шаардлагатай байгаа юм. Эрдэмтэд хорт хавдрын эмчилгээнд химийн аргаар гарган авсан эм бэлдмэлийг хэрэглэхийн сацуу уламжлалт анагаах ухаанд хэрэглэдэг байгалийн гаралтай эм бэлдмэлийг хэрэглэх боломжийг судалж тогтоохыг чухалчилах болов [2]. Иймээс манай оронд элбэг ургадаг ургамлаас төрөл бүрийн бодис гарган шинжлэж, улмаар хорт хавдарын эмчилгээнд хэрэглэх боломжийг судлах нь нилээд чухал юм.

Taraxacum officinale Wigg.S.L буюу Эмийн багваахай нь олон орны уламжлалт эм бэлдмэлийн найрлаганд ордог, хуурай газар ихээхэн тархсан ургамал юм. Энэ ургамлын газрын дээд хэсэг болон үндсийг ил шарх, үү, идээт үрэвслийг анагаах, хоол боловсруулах эрхтэн тогтолцооны ажиллагааг эрүүлжүүлэхэд хэрэглэдэг уламжлалтай тухай зарим ном зохиолд тэмдэглэсэн байна[3].

Нөгөөтэйгүүр, in vitro нөхцөлд аливаа эсийн тогтвортой өсгөвөр гарган авах нь эсийн үйл ажиллагаа, өсөлтийн зүй тогтол, эс хоорондын харилцан үйлчлэл, эсийн онцлог байдлыг судлах, улмаар эсэд химийн болон биологийн гаралтай бэлдмэлүүдийн үйлчлэлийг тогтоох боломжийг олгодог тул ихээхэн ач холбогдолтой загвар систем болно [4]. Иймээс дээрх нөхцөл дахь хорт хавдрын эсийн биологийн үндсэн шинж чанар, үйл ажиллагаа, тухайлбал эсийн хоруу (invasiveness) ба үсэрхийлэх (metastatic) чанар, эсийн хуваагдал, адгези, шилжилт хөдөлгөөн, эс пластик гадаргууд сууж бэхлэгдэх чадвар, апоптозийн процесс, тэдгээрт зарим бодисын үзүүлэх нөлөө зэргийг судлах нь ихээхэн ач холбогдолтой юм.

Бид Эмийн багваахайн газрын дээд хэсгийн этанолон ханд, түүнээс бэлтгэсэн дихлорметан (ДХМ), этилацетат, бутанолон ханд болон ДХМ ханднаас ялгасан цэвэр бодисууд нь элэгний хавдрын НерG2 шугаман эс болон өмнө нь лабораторид гарган авсан элэгний хавдрын анхдагч өсгөврийн эсэд (PCC) хэрхэн нөлөөлж буйг судалсан үр дүнг энэхүү өгүүлэлд танилцуулж байна.

\section{СУДАЛГААНЫ МАТЕРИАЛ АРГА ЗҮЙ}

Ургамлын цуглуулга, дээж бэлтгэх:Эмийн багваахайн (Taraxacum officinale Wigg.S.L., Compositae) газрын дээд хэсгийг 2009 оны 6-р сард ид цэцэглэлтийн үед Улаанбаатар хотын Баянзүрх дүүрэг дэх ШУА-н хүрээлэнгүүдийн цэцэрлэгт хүрээлэнгээс түүж бэлтгэсэн. Ангилал зүйн тодорхойлолтыг ШУА, Ботаникийн Хүрээлэнгийн эрдэм шинжилгээний тэргүүлэх ажилтан ШУ доктор, проф. Ч.Санчир хийж. бидний цуглуулсан ургамал нь дээрх зүйлийн ургамал болохыг тогтоосон.

Хандлах, бүлэглэн хандлах, цэвэр нэгдэл ялгах, бүтэц байгууламж тодорхойлох: $T$. officinale-н 100 г газрын дээд хэсгийг тасалгааны темературт 4 удаа тус бүр 24 цаг 80\%-ийн этанолийн спиртээр хандалж, уусгагчийг вакуум ууршуулагчаар $40^{\circ} \mathrm{C}$-д нэрж зайлуулав. Гарган авсан 53 г өтгөн хандыг цаашид дихлорметан (ДХМ), этилацетат (ЭА), н-бутанол (н-ВuOH) уусгагчуудаар дараалуулан бүлэглэн хандалж, уусгагчийг нэрж зайлуулсны дүнд ДХМ ханд 7.6г, ЭА ханд Зг, н-ВuОН-н ханд 4г тус тус гарган авсан. 
Ханд бүрийн чанарын шинжилгээг $\mathrm{CHCl}_{3}: \mathrm{MeOH}: \mathrm{H} 2 \mathrm{O} / 7: 3: 0.4$ ба $\mathrm{CHCl}_{3}: \mathrm{MeOH}$ :1 системүүдэд нимгэн үеийнхроматографийнаргаархийв. ДХМ-ныхандыгсиликагель

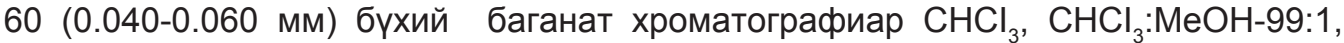
98:2, 97:3, 95:5, 92:8, 9:1, 6:1, 3:1, 1:1 уусгагчийн системээр ялгасан ба силикагель шингээгчтэй баганат хроматографи ашиглан гексан, гексан:этилацетат, ДХМ, ДХМ:МеОН уусгагчийн системүүдийг хэрэглэж 6 бодисыг ялган авч тэдгээрийн фризик химийн шинж чанарыг тодорхойлов. Эдгээр бодисуудын молекулын бүтэц байгууламжийг нэг ба хоёр хэмжээст ${ }^{1} \mathrm{H},{ }^{13} \mathrm{C}$ цөмийн соронзон резонансын (ЦСР) спектрийг JEOL JNM-AL400 FT-NMR, JEOL JNM-EX270 FT-NMR спектрометрт метанол (CD $\mathrm{OD})$, диметил сульфоксид (DMSO-d $\mathrm{d}_{6}$ ) уусгагчид уусган дотоод стандарт тетраметилсилантай харьцуулан хэмжиж тодорхойлсон. Масс спектрийн шинжилгээнд HR-FAB-MS арга хэрэглэв.

Эсийн үржэн олшролын судлагааг ургаж буй эсийн тоог гаргах (Proliferation assay) болон эсийн митохондрийн редуктаза фрерментийн идэвхийг тодорхойлж тооцох (MTT assay) гэсэн 2 аргаар хийсэн. Эсийн митохондрийн редуктаза энзимийн идэвхийг тодорхойлоход уг энзимийн субстрат WST-8 бодисыг ашиглав.

HepG2 ба PCC тус бүрээс $6 \times 10^{3}$ эс/мл эс тооцон авч 24 нүхтэй хавтанд 5\% $\mathrm{CO}_{2}, 37^{\circ} \mathrm{C}-д$ өсгөвөрлөв. RPMI-1640 тэжээлийн орчинд байх ургамлын хандуудын эцсийн концентрацийг 25 мкг/мл, 100 мкг/мл, 250 мкг/мл, 500 мкг/мл, харин цэвэр бодисуудынхыг 5 мкг/мл, 10 мкг/мл, 25 мкг/мл, 50 мкг/мл, 100 мкг/мл байхаар тооцон 48 цаг эсэд үйлчлүүлсэн. Трипсинийг ашиглан эсүүдийг салгаж эсийн суспензи үүсгэж Neubauer-ийн тор ашиглан эсийг тоолов.

HepG2 эсийг ижил тоогоор 96 нүд бүхий хавтанд тарьж, 2.5 мкг/мл, 5 мкг/мл, 10 мкг/мл, 25 мкг/мл, 50 мкг/мл концентрацитай пальмитиний хүчлил бүхий тэжээлийн орчинд өсгөвөрлөв. Митохондрын редуктаза энзим нь WST-8 субстратад үйлчилж түүнийг формазин болгон задалдаг учир эсийн өсгөвөрт WST-8 нэмж 1 цагийн турш байлгасны дараа дээрх энзимийн үйлчлэлийн дүнд үүссэн уусамтгай формазины хэмжээг гэрэл шингээлтийн 450 нм-ийн утганд хэмжиж тодорхойлов.

Эс хоорондын наалдах (Adhession Assay) ба гадаргууд эсийн суух чадварын шинжилгээ (Spreading assay): Өсгөврийн аяганы ёроолд эсүүд суусны дараа ханд болон цэвэр бодистой орчинг хийж дахин 48 цаг өсгөвөрлөв. Трипсинээр үйлчлүүлж бэлдсэн 5 × $10^{5}$ эс/мл (500 эс/мкл) суспензээс авч 1, 2, 3, 4, 5 цаг өсгөвөрлөсөний дараа хоорондоо наалдсан эсүүд буюу эсийн бөөгнөрлүүдийг тоолов. Үүнээс тусад нь дээрх аргаар эсүүдийг өсгөвөрлөж 1, 2, 3 цаг тус бүрийн дараа аяганы ёроолд наалдаж ургасан эсүүдийг мөн тоолов.

Эсийн шилжин хөдлөх чадварын шинжилгээ (Migration assay): Өсгөврийн аягануудад тодорхой тооны эсийг $37^{\circ} \mathrm{C}-д$ эсийн нэг давхрага үүстэл өсгөвөрлөв. Эсийн гадаргуу дээр зохиомлоор шарх үүсгэж 1хPBS-ээр угаасны дараа хандтай тэжээлийн орчин хийж шархны анхны хэмжээ болон 24, 48, 72 цагийн дараах хэмжээний зургуудыг Tsview программ ашиглан авч хэмжилт хийв. Үр дүнг Microsoft Excel программ ашиглан боловсруулав [5].

Апоптозийн шинжилгээ (Apoptosis assay): PCC эсийг 100 мкг/мл, 200 мкг/мл, 300 мкг/мл хандаар, харин НерG2 эсийг 10 мкг/мл, 25 мкг/мл, 50 мкг/ мл концентрацитай пальмитиний хүчилтэй ба уг бодис үгүй RPMI-1640 тэжээлт орчинд тус тус 48 цаг өсгөвөрлөв. Эсүүдийг 1хPBS-ээр угаасны дараа этидиум бромид/акридин улбар шар бодисыг хамтад нь ашиглан будаж фллуоресценци микроскопоор зургийг авч тооцоолов [6]. 
Генийн экспрессийн шинжилгээ (Gene expression assay): Хавдрын үед ихээхэн идэвхждэг зарим маркер генүүд болох ZFYVE1 (мембран транспорт), GPC3 (эсийн гадаад матрикс), SH3BGR (эсийн бодисийн солилцоо), GPR175 (органогенез) ба h-Ras, Fak, Bcl-2 онкогенүүд болон TNF-a, p53, апоптозийн процесст түлхүүр үүрэг гүйцэтгэдэг CASP-3 генүүдийн экспрессийн судалгааг ургамлын хандаар үйлчилсэн болон үйлчлээгүй эсүүдээс ялгасан PHХ ашиглан RT-PCR-ийн аргаар хийв.

\section{СУДАЛГААНЫ ҮР ДҮН, ШҮҮН ХЭЛЭЛЦҮҮЛЭХҮЙ}

\section{ДХМ ханднаас ялгасан бодисууд}

Элэгний хавдрын эсийн эсрэг идэвхтэй үйлдэлтэй ДХМ-н ханднаас баганат хроматографийн аргаар 6 бодис ялгаж, тэдгээрийн физик химийн шинж чанар, протон ба нүүрстөрөгчийн ЦСР-н спектроскопын аргуудаар молекулын бүтэц байгууламжийг тараксастерилацетат (1), псевдотараксастерол (2), тараксастерол (3), b-ситостерол (4), пальмитиний хүчил (5), b-ситостерил глюкоз (6) гэж таньж тодорхойлов (1-р зураг). T.officinale ургамлын химийн найрлага харьцангуй сайн судлагдсан бөгөөд түүнд тритерпен, стерол, флавоноид, полисахар, фритил тосны хүчил агуулагддаг болохыг бусад судлаачид тогтоожээ $[7,8]$. Харин пальмитиний хүчил ялгасан тухай мэдээлэл олдсонгүй.

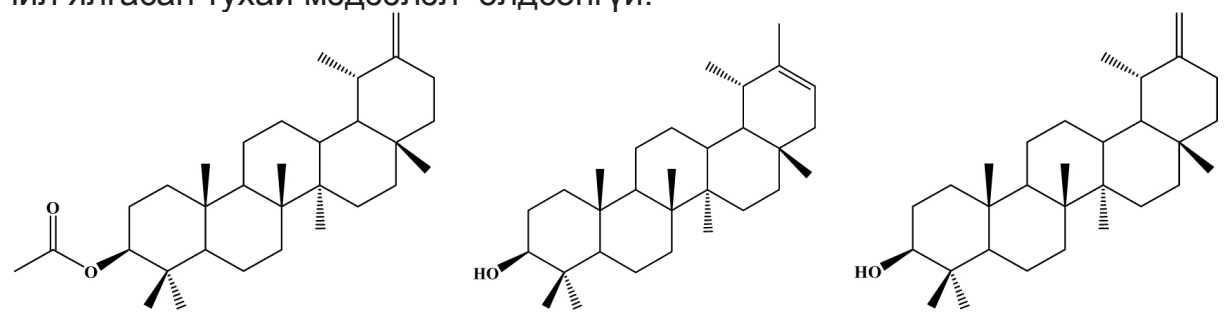<smiles>C=CCCCC(=C)CCCCCCCCC(=O)O</smiles>

\section{5}

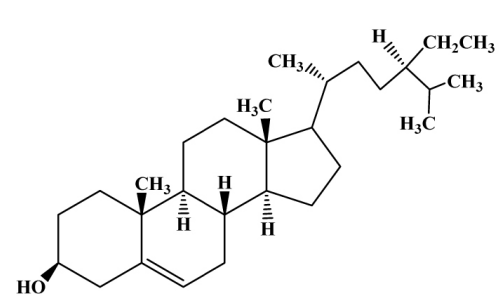

4

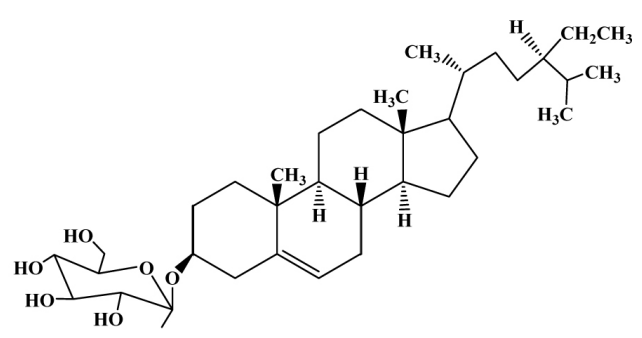

6

1-p зураг. Т.officinale-н ДХМ ханднаас ялгасан бодисууд тараксастерилацетат (1), псевдотараксастерол (2), тараксастерол (3), b-ситостерол (4), пальмитиний хүчил (5), b-ситостерил глюкоз (6) 
T.officinale-н газрын дээд хэсгийн хандуудын РСС эсийн хуваагдалд үзүүлсэн нөлөө:

Эмийн багваахайн газрын дээд хэсгээс цэцэгт ишний этанолон ханд, түүнээс ДХМ, ЭА, н-ВuOH ханд, усан үлдэгдэл болон цэцэг ба үрийн этанолон ханд бэлтгэж, эсэд тодорхой концентрациар үйлчлүүлж эдгээр нь хуваагдалд хэрхэн нөлөөлж буйг судлахад 6 ханд нь концетрациас хамааралтайгаар эсийг үхүүлэх эсвэл эсийн хуваагдлыг саатуулах нөлөөтэй байв (2-р зураг). Эдгээрээс ДХМ хандны эсийн хуваагдлыг дарангуйлах идэвхи нь бусад ханднаас илүү байсан учир түүнийг сонгож цаашид нарийчвлан судлахад уг ханд нь эс-эс хоорондын наалдах чадварыг 34.5\%, шилжин хөдлөх чадварыг 36\%-р тус тус бууруулах нь ажишлагдав. Түүнчлэн ДХМ хандаар үйлчилсэн эсүүдийн гадаргууд суух чадвар хандаар үйлчлээгүй (хяналтын) эсүүдийнхтэй харьцуулахад 2.6 дахин буурсан байв.

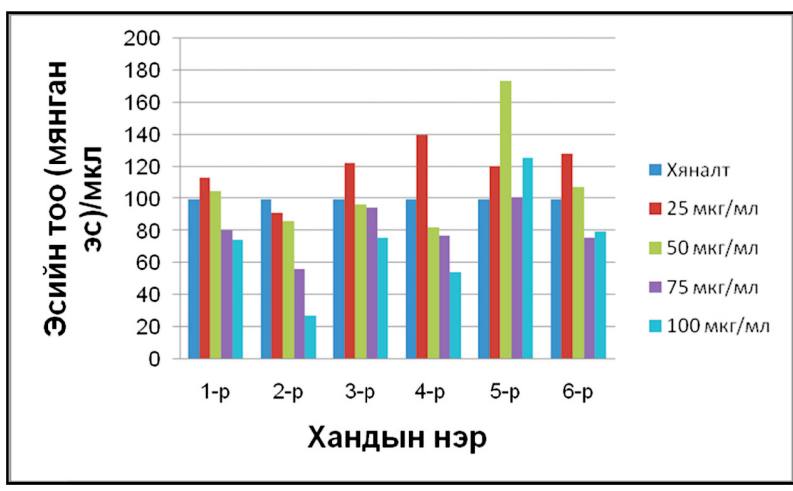

2-p зураг. T.officinale-н газрын дээд хэсаийн хандуудын эсийн хуваагдалд үзүүлсэн нөлөө.

1-р ЭА ханд, 2-р ДХМ ханд, 3-р цэцэгт ищний $80 \%$-н этанолон ханд, 4-р н-ВиОН ханд, 5-р цэцэгт ишний усан үлдэгдэл, 6-р цэцэг, үрийн 80\%-н этанолон ханд

\section{ДХМ хандны РСС эсийн генүүдийн экспресст үзүүлсэн нөлөө:}

ДХМ хандаар үйлчилсэн болон үйлчлээгүй эсүүдэд CASP-3 генийн экспресс RT-PCR аргаар илрээгүй. Харин ZFYVE1 генийн экспресс 42\%, SH3BGR -9\%, BCL2- 50\%, GPR175- 50\%-р тус тус буурсан бол GPC3 генийн экспресс 46\%-р нэмэгдсэн байв (3-р зураг). Энэ нь ДХМ ханд эсийн наалдах чадварт нөлөөлж хавдар үсэрхийлэх, эсүүд хоорондоо наалдах чадварыг бууруулж, хавдрын эсийг үхүүлж болохыг харуулж байна. ZFYVE1, SH3BGR генүүд нь эс хоорондын наалдах, мөн эсүүдийн гадаргууд суух процесс явагддаг негтин, интегрин, кадхерин, селектин, JAMs (junctional adhession molecules) зэрэг трансмембраны уургуудыг кодолоход оролцдог [9]. Харин CASP-3 генийн экспресс эсүүдэд илэрээгүй нь T.officinale-н ДХМ хандны элэгний хавдрын эсүүдэд үүсгэж буй апоптозийн процесс нь CASP-3 уургаас үл хамаарсан буюу каспазаас үл хамаарах апоптози байж болох магадлалтайг харуулна.

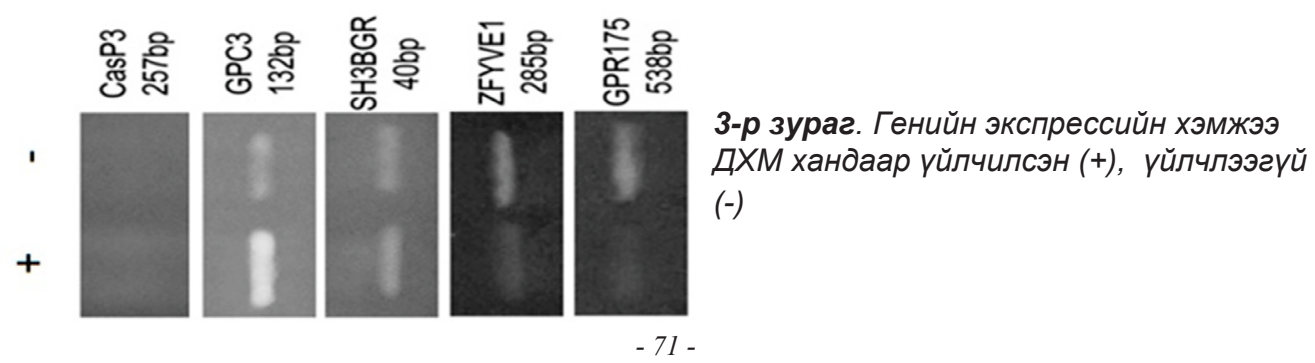




\section{Пальмитиний хүчлийн НерG2 эсийн хуваагдалд үзүүлсэн нөлөө:}

Ялгасан цэвэр бодис тус бүрийг 2.5 мкг/мл, 5 мкг/мл, 10 мкг/мл, 25 мкг/мл, 50 мкг/мл концентрацитайгаар бэлтгэж HерG2 эсийн хуваагдалд хэрхэн нөлөөлж буйг үзэхэд эдгээрээс пальмитиний хүчил буюу 5-р бодис эсийн хуваагдлыг концентрациасхамаарсан саатуулжбайв (4-зураг). Ялангуяа 50 мкг/мл пальмитиний хүчил нь эсэд маш хүчтэй нөлөөлж эсийн хуваагдлыг зогсоож, үхүүлсэн байв.
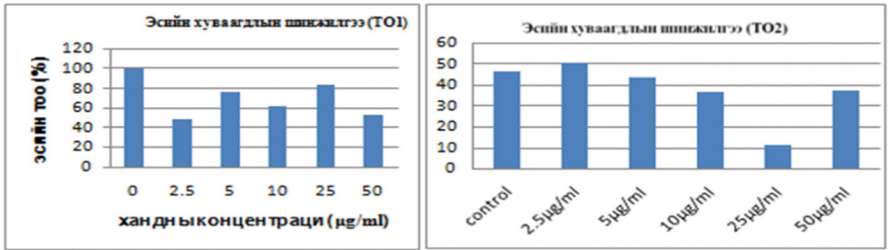

4-p зурае. 1, 2, 3, 4, 5, 6 бодисуудаар үйлчилсэн болон үйлчлээгүй эсүүдийн хуваагдал, тооны өөрчлөлт
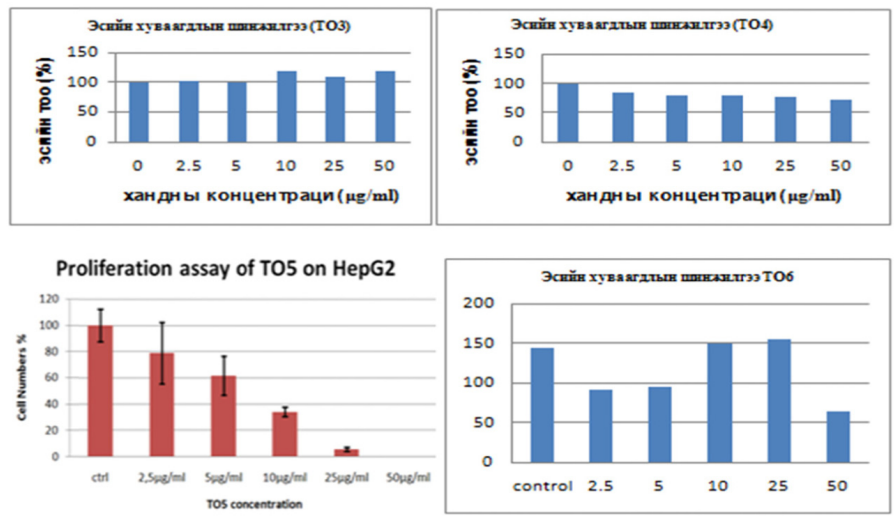

Мөн HepG2 эсийг 2.5 мкг/мл, 5 мкг/мл, 10 мкг/мл, 25 мкг/мл, 50 мкг/мл концентраци бүхий пальмитиний хүчилтэй өсгөвөрлөхөд тэдгээрийн митохондрын редуктаза энзимийн идэвхи концентрациас хамаарч буурч байгаа үр дүн ажиглагдав (5-р зураг). Үйлчлэгч бодисын концентраци ихсэх тутам энзимийн идэвхи буурч байгаа нь амьд эсийн тоо буюу эсийн хуваагдал багасч байгаатай холбоотой юм.

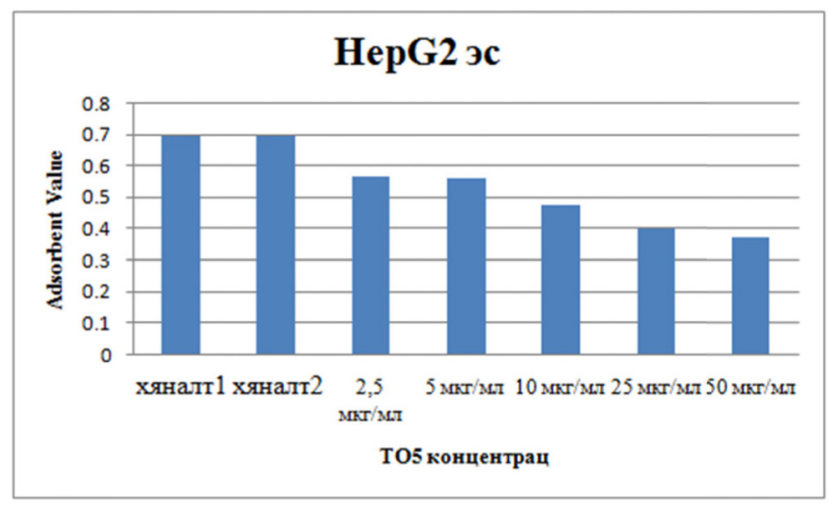

5-рзураг.Митохондрынредуктаза энзимийн идэвхи ба үйлчилсэн пальмитиний хүчлийн хамаарал (Т05 концентраци - пальмитиний хүчлийн концентраци) 


\section{Пальмитиний хүчлийн эс хоорондын наалдах чадварт үзүүлсэн нөлөө:}

Пальмитиний хүчлээр үйлчилсэн эсүүдийн өөр хоорондоо наалдах чадвар тухайн бодисоор үйлчлээгүй хяналтын эсүүдийн наалдах чадвараас дунджаар 5.2\%-р буурсан байв (6-р зураг). Эсүүд хоорондоо холбогдоход трансмембраны уургууд чухал үүрэгтэй оролцдог тул пальматиний хүчил эдгээр уургийн экспресст сөрөг нөлөөтэй байж болох юм.

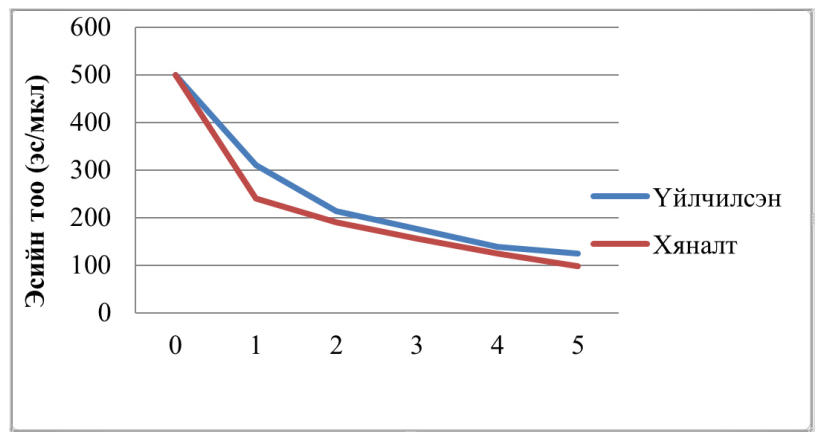

6-р зураг. Пальмитиний хүчлээр үйлчилсэн болон үйлчлээгүй хяналтын эсүүдийн тоог өлгөгдсөн дусалд инкубацилан харьцуулсан үзүүлэлт.

\section{Пальмитиний хүчлийн НерG2 эсийн гадаргууд суух чадварт үзүүлсэн нөлөө:}

Уг бодисоор үйлчилсэн болон үйлчлээгүй хяналтын эсүүдийн гадаргууд суух чадварыг харьцуулан шинжлэхэд пальмитиний хүчил бүхий орчинд ургуулсан эсийн суух чадвар хяналтын эсүүдийнхээс 41.6\%-р буурсан байв (7, 8-р зураг). Хяналт болон туршилтын эсүүд 20 дахь минутаас гадаргууд сууж эхэлсэн бөгөөд 80 дахь минутаас хяналтын эсүүд гадаргууд хурдацтай сууж эхэлсэн бол харин туршилтийн эсүүд нилээд удаан сууж байв.

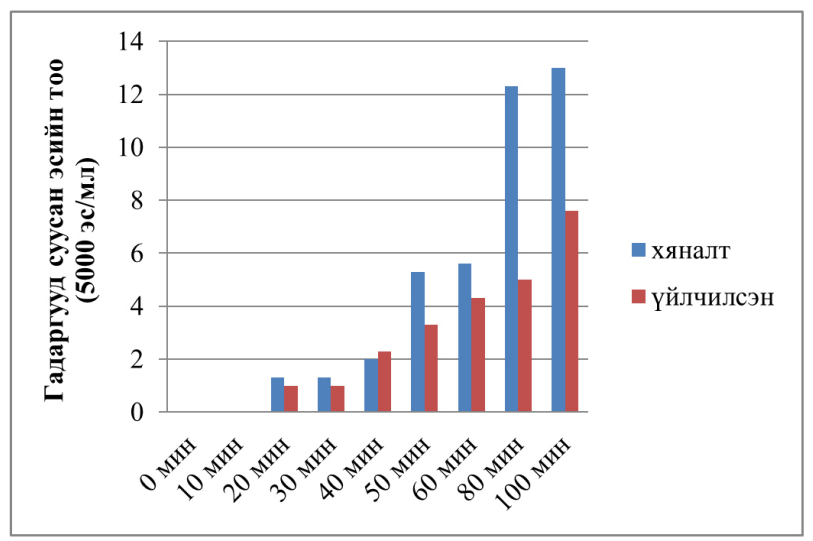

7-р зурае. Хавдрын эсийн суух чадварт пальмитиний хүчлийн үзүүлсэн нөлөөний харьцуулсан үзүүлэлт 


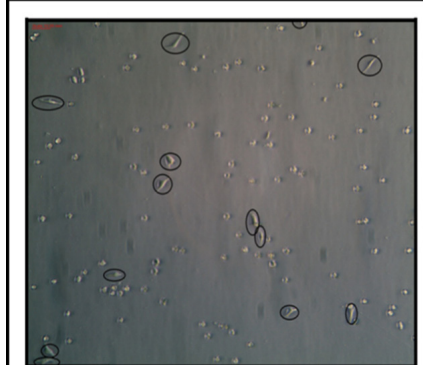

Хяналт

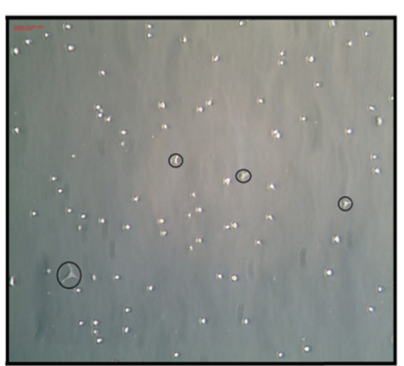

үйлчилсэн

8-р зураг. Пальмитиний хүчлээр үйлчилсэн ба үйлчлээгүй хяналтын эсүүдийн гадаргууд суусан байдал. Эсүүдийг тарьснаас 100 минутын дараа зургийг авав. Гадаргууд суусан эсүүдийг хар өнгөөр дугуйлж тэмдэглэв.

\section{Пальмитиний хүчлийн эсийн шилжин хөдлөх чадварт үзүүлсэн нөлөө:}

Эсийг пальмитиний хүчлээр үйлчлэхэд уг эсийн шилжин хөдлөх чадвар харьцангуй хурд дунджаар 0.67 мм/цаг, харин хяналтын эсийн шилжин хөдлөх хурд дунджаар 0.73 мм/цаг байсан (9,10-р зураг) нь T. officinale -гаaс ялгасан пальмитиний хүчил нь элэгний хавдрын эсийн шилжин хөдлөх чадварыг ойролцоогоор 8.2\%-р бууруулж байгааг харуулж байна.
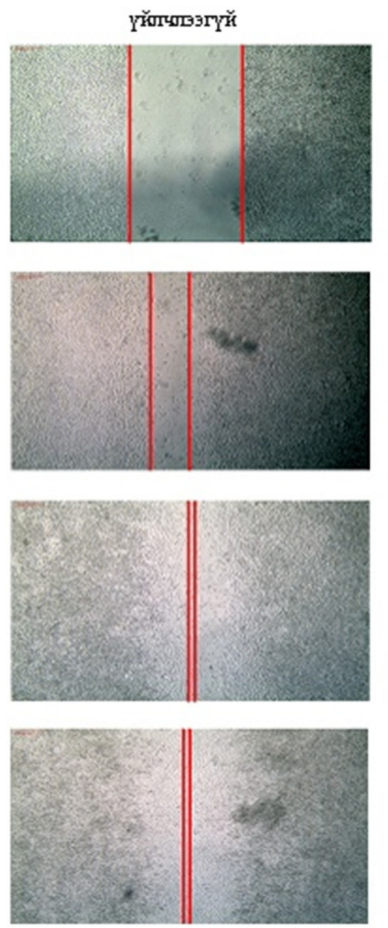

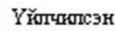
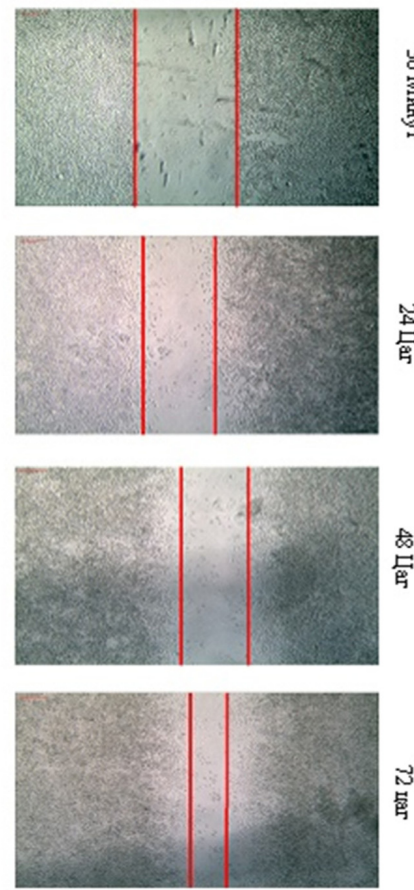

9-р зураг. Пальмитиний

㟔 $\quad$ хүчлээр үйлчилсэн ба үйлчлээгүй эсүүдийн хугацаанаас хамаарч шилжин хөдлөж шархыг бүрхэн ургасан байдал. 


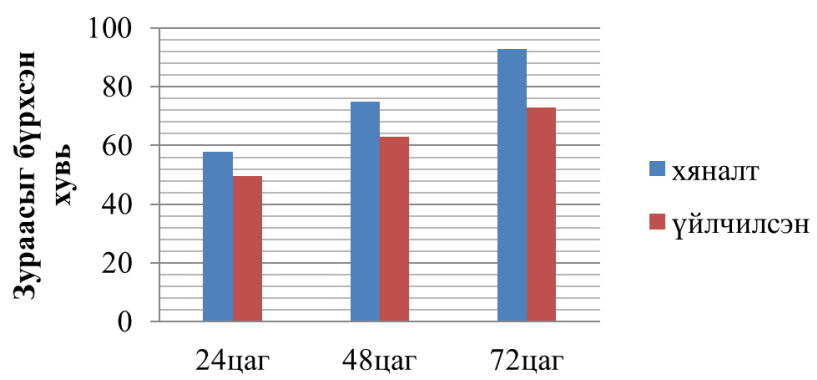

10-р зураг. Пальмитиний хүчлээр үйлчилэхэд эсүүдийн шилжин хөдлөх хурдыг харьцуулсан диаграмм

Пальмитиний хүчлийн HерG2 эсийн апоптози ба эсийн бүтцийн эвдрэлд үзүүлсэн нөлөө:

11-р зургаaс харахад HepG2 эсийг 10 мкг/мл, 25 мкг/мл, 50 мкг/мл концентрацитай пальмитиний хүчлээр үйлчлэхэд 50 мкг/мл үед эсийн бүтцийн эвдрэл болон апоптозид ажиглагдаж байв. Акридин улбар шар нь эсийн бөөмийг ногооноор буддаг бол этидиум бромид нь эсийн мембран бүтэц эвдрэх үед л эсэд шингэж бөөмийг улаанаар буддаг. Харин хэвийн, амьд эсүүд ногоон өнгөтэй харагддаг. Апоптозийн эхний шатанд байгаа амьд эсүүд жижгэрч хуваагдсан хроматинтай, шаргал эсвэл улбар шар бөөмтэй харагддаг бол апоптозийн сүүлийн шатанд орсон эсийн бөөм улаан өнгөтэй харагддаг.

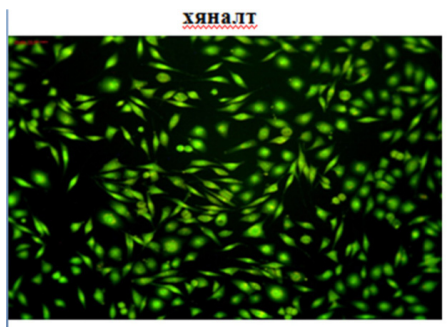

$25 \mathrm{MKr} / \mathrm{MJ}$

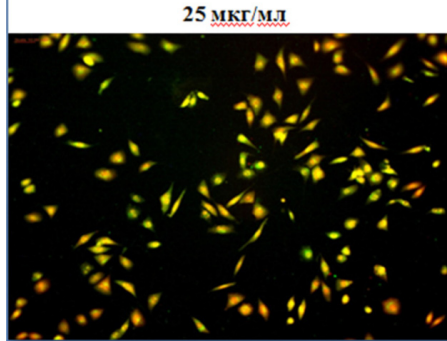

$10 \mathrm{MKr} / \mathrm{Mл}$

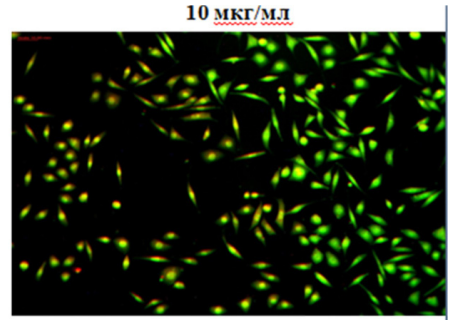

$50 \mathrm{MKr} / \mathrm{MJ}$

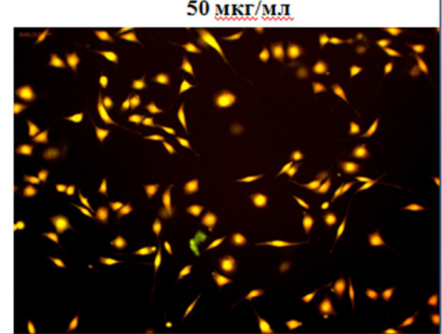

10-р зураг. Пальмитиний хүчлийн концентрациас хамаарч НерG2 эс апоптози болон бүтцийн эвдрэлд орсон байдал.

Хавдрын эсийн үсэрхийлэл болон хоруу чанар нь тэдгээрийн үржин олшрох, эс хоорондын наалдах, эс гадаргууд сууж бэхлэгдэх, эсийн шилжин хөдлөх чадвар, апоптози зэрэг хэд хэдэн биологийн шинжээр тодорхойлогддог нарийн нийлмэл процесс юм.

Бусад судлаачдын судалгаанаас үзэхэд пальмитиний хүчил нь концентраци ба хугацаанаас хамаарч элэгний хавдрын HерG2 эсийн өсөлтийг саатуулдаг байна [10]. Пальмитиний хүчил нь тунгаас хамаарч нойр булчирхайн MIN6 эсийн апоптозийг өдөөсөн байна [11]. Пальмитиний хүчил нь галууны элэгний эсэд триглицерид хуримтлагдахыг идэвхижүүлсэн ба элэгний эс апоптози 
болохыг нөхцөлдүүлж байсан бөгөөд энэ нөлөө нь липидийн солилцооны замтай холбоотой байж болох талтай гэж үзжээ[12]. In vivo нөхцөлд пальмитиний хүчил нь тун ба хугацаанаас хамаарч хархны элэгний эсэнд эсийн өсөлтийг зогсоох нөлөөтэйг тогтоосон байна[13]. ( Мөн T. officinale-н гаралтай ханд хөхний болон түрүү булчирхайн хорт хавдарын эсийн үйл ажиллагааг дарангуйлж байсныг зарим судлаачид харуулжээ[14]. Ийнхүү бусад судлаачдын судалгааны үр дүн [15] болон бидний судалгаанаас пальмитиний хүчил нь апоптозийг өдөөдөг, мөн эсийн бүтцийн эвдрэл үүсгэж байгаа нь тодорхой байна. Хэдийгээр бидний судалгааны дүнд $T$. officinale-н ДНХ ханд нь зарим генийн экспрессийг дарангуйлж байсан нь илэрсэн ч цаашид пальмитиний хүчил хавдарын эсийн хуваагдал болон апоптозийн маркер генүүдийн экспресст нөлөөлөх молекул механизмыг судлан тайлбарлах нь чухал юм.

Бид энэхүү судалгааны үр дүнд тулгуурлаж Эмийн багваахай буюу $T$. officinale-н газрын дээд хэсгийн дихлорметанан ханд, түүнээс ялгасан пальмитины хүчил нь элэгний хавдрын эсийн үйл ажиллагаанд сөрөг нөлөөтэй байж болох магадлалтай гэж дүгнэв.

\section{Ашигласан хэвлэл}

1. www.int/cancer/en

2. Abstracts for International PSE Symposiums on Natural Products in Cancer Therapy, Naples, Italy, Sep 23-26, 2008.

3. Лигаа У., Даваасүрэн Б., Нинжил Н.: Монгол орны эмийн ургамлыг өрнө дорнын анагаах ухаанд хэрэглэхүй, JKC printing, Улаанбаатар, 66-70, 2006.

4. Cell culture models of biological barriers in vitro test systems for dry absorption \& delivery. Ed.G.M.Lehr, 2002.

5. Liang CC, Park AY, Guan JL. In vitro scratch assay: a convenient and inexpensive method for analysis of cell migration in vitro. Nat Protoc; 2(2):329-338,2007.

6. Deborah R, Nathaniel B G, David A N and Yiqun G S "A simple technique for quantifying apoptosis in 96-well plates" BMC Biotechnology, 2005)l.

7. Takasaki M, Konoshima T, Tokuda H, Masuda K, Arai Y, Shiojima K and Ageta H: Anticarcinogenic activity of Taraxacum plant I. Biol Pharm Bull 22: 602-605, 1999.

8. Koo HN, Hong SH, Song BK, Kim CH, Yoo YH, Kim HM. Taraxacum officinale induces cytotoxicity through TNF-alpha and IL-1alpha secretion in Hep G2 cells. Life Sci; 74: 1149-1157, 2004.

9. Raschperger E, Engstrom U, Pettersson RF, Fuxe J. CLMP, a novel member of the CTX family and a new component of epithelial tight junctions. J Biol Chem: 279(1), 2004.

10. Zhang L, Ji J, Zhu XY, Wu YY, Yu H, Zhang B, Li XL, Sun XZ. "Palmitic acid induces apoptosis in human hepatoma cell line, HepG2 cells" Zhongguo Yi Xue Ke Xue Yuan Xue Bao.26(6):671-6, 2004.

11. Liu L, Wang RP, Liu XH, Wang LX, Liu XY, Chen WJ, Liu LB. The chronic effect of palmitic acid on apoptosis of pancreatic islet beta-cells and the mechanism. Zhongguo Ying Yong Sheng Li Xue Za Zhi. 25(4):553-6,2009.

12. Pan Z, Wang J, Tang H, Li L, Lv J, Xia L, Han C, Xu F, He H, Xu H, Kang B. Effects of palmitic acid on lipid metabolism homeostasis and apoptosis in goose primary hepatocytes. Mol Cell Biochem. 2010.

13. Kim, H.M., Shin, H.Y., Lim, K.H., Ryu, S.T., Shin, T.Y., Chae, H.J., Kim, H.R., Lyu, Y.S., An, N.H., Lim, K.S. Taraxacum officinale inhibits tumor necrosis factor-alpha production from rat astrocytes. Immunopharmacology and Immunotoxicology 22 (3), 519-530, 
2000.

14. Sigstedt S.C., Hooten CJ, Callewaert MC, Jenkins AR, Romero AE, Pullin MJ, Kornienko A, Lowrey TK, Slambrouck SV, Steelant WF Evaluation of aqueous extracts of Taraxacum officinale on growth and invasion of breast and prostate cancer cells. Int J Oncol 32, 1085-90, 2008.

15. Ji J, Zhang L, Wang $P$, Mu YM, Zhu XY, Wu YY, Yu H, Zhang B, Chen SM, Sun XZ. Saturated free fatty acid, palmitic acid, induces apoptosis in fetal hepatocytes in culture. Exp Toxicol Pathol.56(6):369-76, 2005. 


\title{
LIVER CANCER IN VITRO CELL FUNCTIONS ARE SUPPRESSED BY SOME COMPOUNDS ISOLATED FROM TARAXICUM OFFICINALE WIGG F.H.
}

\author{
J.Boldbaatar ${ }^{1}$, B.Tuvshintugs ${ }^{1}$, O.Odgerel ${ }^{1}$, G Odontuya ${ }^{2}$, R.Sanduijav ${ }^{3}$, \\ P.Erdenebaatar ${ }^{1}$, Oyunsuren ${ }^{1}$ \\ ${ }^{1}$ Laboratory of Molacular Biology, Institute of Biology, MAS, \\ ${ }^{2}$ Laboratory of Natural Product Chemistry, Institute of Chemistry and Chemical Technology, MAS \\ ${ }^{3}$ National Cancer Research Center \\ Corresponding address: tsosuren@yahoo.com
}

\section{ABSTRACT}

Liver cancer or Hepatocellular carcinoma ( $\mathrm{HCC})$ is one the most prevalent cancer globally. Prevention, early diagnosis as well as cancer treatment are important problems , especially in Mongolia where HCC rate has being continuously increased during last decades among the population.

The aim of the present work was to study effects of some extracts and compounds isolated from widely used traditional medicine Taraxicum officinale Wigg FH for some functions of $\mathrm{HCC}$ in vitro cell culture; HepG2 and PCC, the primary cell culture established from HCC in-house.

Dichloromethane and other 4 extracts, and taraxasterel acetate , psi-taraxasterol, taraxasterol, b-sitosterol, palmatic acid, b-sitosterol glucose were isolated from T.officinale and used for our experiments. Dichloromethane extract negatively affected for cell proliferation, and cell migration, spreading, adhesion and comparing to controls these abilities were decreased by $36 \%, 2.6$ times and $34.5 \%$ respectively. Also Bcl-2 and ZPYVE-1 gene expressions were suppressed.

From six compounds isolated from dichloromethane extract, the palmatic acid has more effects for HCC functions than others, suppressing cell proliferation, migration, adhesion and activated a cell apoptosis.

From results of our study it was concluded that, T.officinale derived dichloromethane extract and palmatic acid negatively effects for liver cancer in vitro cell culture functions. 